\title{
ORGIA DAS (DES)HUMANIDADES: TRAUMA, MEMÓRIA E VIOLÊNCIA EM CONTOS DE UNGULANI BA KA KHOSA
}

\section{ORGY OF (IN)HUMANITIES: TRAUMA, MEMORY AND VIOLENCE IN TALES WRITTEN BY UNGULANI BA KA KHOSA}

Tales Santos Pereira ${ }^{1}$ Universidade Estadual de Santa Cruz (UESC)

\section{RESUMO}

Discutimos a seguinte problemática: de que modo nos contos "A orgia dos loucos" e "O exorcismo", que integram a obra Orgia dos loucos, de Ungulani Ba Ka Khosa (2016), enquanto representantes da literatura moçambicana, apresentam relações entre trauma, memória e violência relativas à realidade social vivenciada em Moçambique? Para tanto, realizamos um estudo essencialmente de cunho bibliográfico, com base nas discussões sobre trauma, violência e literatura encontradas em Ginzburg (2004, 2011, 2012) e Seligmann-Silva (2008, 2016). Enquanto resultado de análise, acreditamos que o autor em estudo elabora, nessas narrativas, uma linguagem hiperbólica da destruição, verdadeira orgia de corpos jogados no abismo da morte e da desumanização.

PALAVRAS-CHAVE: Literatura moçambicana. Guerra civil. Orgia dos loucos.

\section{ABSTRACT}

It discusses the following issue: how the stories of the book Orgia dos loucos (Orgy of the mad), written by Ungulani Ba Ka Khosa (2016), specifically the tales "A orgia dos loucos" ("The orgy of the mad") and "O exorcismo" ("The exorcism"), as representatives of the Mozambican literature, present relations between trauma, memory and violence of the social reality experienced in Mozambique? Therefore, it is an essentially bibliographic study, based on the discussions about trauma, violence and literature promoted by Ginzburg $(2004,2011,2012)$ and Selligmann-Silva $(2008,2016)$. As a result of its analysis, we believe that this author elaborates, in these narratives, a hyperbolic language of destruction, a real orgy of bodies thrown into the abyss of death and dehumanization.

KEYWORDS: Mozambican literature. Civil war. Orgia dos loucos (Orgy of the mad).

\section{INTRODUÇÃO}

As aproximações entre trauma, memória e violência, enquanto matéria da vida, foram e ainda são relevantes fontes para a literatura. No contexto das sociedades africanas, em especial as que foram colonizadas por Portugal, emergem, assim, relatos (literários, fílmicos, depoimentos etc.) de histórias individuais e coletivas bruscamente interrompidas, de existências intensamente violentadas de muitas formas, tanto em meio à dominação portuguesa quanto na luta pela libertação e (re)construção de cada país enquanto nação.

As narrativas sobre o trauma redimensionam e tencionam o campo das memórias, possibilitando a (re)inscrição na história e na literatura de perspectivas pouco visibilizadas pela tradição historiográfica e canônica. Efetivamente, a partir da narração dos eventos traumáticos em contextos de violências e opressões sistemático-institucionais, os sistemas de representação

${ }^{1}$ Mestre e Doutorando em Linguagens e Representações pela Universidade Estadual de Santa Cruz. Membro do GPBIOH (Grupo de pesquisa "O espaço biográfico no horizonte das literaturas homoeróticas"), certificado pelo CNPq. E-mail: tspereira@uesc.br. 
consagrados no mundo ocidental se veem abalados pela fragmentação e incapacidade de organização racional dos indivíduos frente a eventos catastróficos.

Ao analisar as literaturas africanas de língua portuguesa pela perspectiva das narrativas do trauma, observamos a emergência de vozes e discursos que denunciam as dores e fantasmas do passado causados pelo colonialismo na África, bem como da subsequente estrutura de dominação e opressão deixada após os complexos movimentos de independência. Além disso, alguns desses países, a exemplo de Angola e Moçambique, experimentaram sangrentas guerras civis em seus respectivos territórios no período imediatamente posterior a sua emancipação política.

Nesse gesto de narrar os acontecimentos históricos traumáticos, os escritores africanos assumem um comprometimento ético, estético e político em suas obras. Ao entrelaçar história, memória e ficção, eles rasuram os termos de uma historiografia ocidental asséptica, a qual elimina toda a sujeira e sangue causados pela civilização e pelo progresso colonial, para construir o futuro de suas nações pensando nas dores e cicatrizes do passado, a fim de construir sociedades livres dos sistemas opressivos e que desumanizam sujeitos (MOREIRA, 2015).

Em vista disso, objetivamos, no presente trabalho, analisar os contos referidos da coletânea de $\mathrm{Ba} \mathrm{Ka}$ Khosa, evidenciando relações entre trauma, memória e violência. Por meio de uma escrita sem pudores, ao colocar o leitor no centro da carnificina da guerra civil em Moçambique ou denunciando o apagamento das comunidades tradicionais durante o governo pós-independência, o autor elabora, nesses contos, uma linguagem hiperbólica da destruição, na medida em joga com os caracteres da ruína e nos expõe aos cadáveres, às vísceras e aos horrores de uma verdadeira orgia de corpos jogados no abismo da morte e da desumanização.

\title{
1 Entre fantasmas, dores e escritas
}

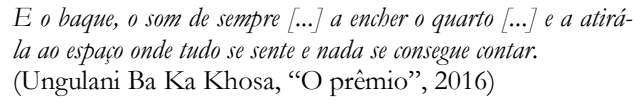

A natureza do trauma afeta diretamente o modo como o indivíduo assimila, organiza e produz sentidos. Esse choque com o real desestabiliza os processos de rememoração, modificando profundamente o fluxo de lembranças do sujeito nas relações que estabelece com a realidade e os dispositivos de representação do simbólico. Por certo, qualquer tentativa de racionalização do evento traumático esbarra na impossibilidade de acessá-lo diretamente. (SELIGMANN-SILVA, 2008).

De acordo com Silva (2015, p. 19, grifos nossos), no estado de choque traumático:

\begin{abstract}
A literalidade brutal de um momento vivido pode ultrapassar nossa capacidade de compreensão ao ponto de impedir-nos de adentrar com ele no plano do simbólico, plano onde ocorre a transformação do real em narrativas acessíveis e intercambiáveis. Se os fatos que ocorrem em nossa vida passam sempre pelo crivo da compreensão de suas motivações racionais ou emocionais, o trauma seria então a impossibilidade desse processo.
\end{abstract}

Ademais, essa impossibilidade de racionalizar o trauma é potencializada pela sensação de terror e vulnerabilidade que se instala no modo como o sujeito percebe as memórias, a realidade, as emoções e a si mesmo. Tais percepções são fragmentadas e assombram o indivíduo pela repetição insistente em flashs, como se a natureza não assimilada do abalo traumático proporcionasse um atraso no processo de rememoração.

Assim, a memória fragmentária do trauma surge de forma irruptiva, sem lugar ou momento específico para aparecer, numa cadeia contínua de flashbacks. Com a impossibilidade de organização racional no plano simbólico, as memórias traumáticas permanecem encriptadas na 
consciência, manifestando-se naquilo "que permanece não conhecido por nossas ações e na nossa linguagem" (WALTER, 2011, p. 02).

Se, por um lado, é impossível acessar o trauma de forma simples e direta, por outro, há de se considerar sua manifestação indireta inscrita no corpo-testemunha. Desse modo, "o trauma encontra na imaginação um meio para a sua narração” (SELIGMANN-SILVA, 2008, p. 70), posicionando o sujeito em um vórtice de imagens, sons, lembranças, cores, sentidos, sentimentos que se entrelaçam e se confundem nos múltiplos planos narrativos que derivam dessa experiência.

De forma geral, quando conseguem expor/expressar o trauma, os participantes silenciados relatam o evento traumático mediante a reconstrução do passado a partir das memórias individuais, as quais se originam, por vezes, de uma memória coletiva, visto que as lembranças são formadas no interior de um grupo. Nesse sentido, a memória se apoia sobre um fato vivido, o qual permite que o sujeito, naturalmente, reconstrua o acontecimento passado, fornecendo mais do que o passado apreendido pela história escrita (HALBWACHS, 1990). Assim, o não esquecimento e a memória dos acontecimentos passados passam a ter também o compromisso e a força para lutar pelo futuro e redimir os martirizados e silenciados pelos traumas vividos (BENJAMIN, 1983).

Nessa abordagem, o procedimento literário pode contribuir com o processo de narração daqueles que necessitam contar o fato traumático, passar adiante a terrível experiência vivida, conforme aponta Márcio Seligmann-Silva. Para esse autor, "a literatura é chamada diante do trauma para prestar-lhe serviço" (2008, p. 70), porque:

\begin{abstract}
está na vanguarda da linguagem: ela nos ensina a jogar com o simbólico, com as suas fraquezas e artimanhas. Ela é marcada pelo 'real' - e busca caminhos que levem a ele, procura estabelecer vasos comunicantes com ele. Ela nos fala da vida e da morte que está no seu centro [...], do visível e da moldura que não percebemos no nosso estado de vigília e de constante Angst - diante do pavor do contato com as catástrofes externas e internas (SELIGMANN-SILVA, 2002, p. 145, grifos do autor).
\end{abstract}

Potencialmente, a literatura configura-se como um campo fértil para as narrativas do trauma. Essa relação começou a ser estudada após a Segunda Guerra Mundial, principalmente com as pesquisas voltadas para os relatos dos sobreviventes do holocausto. Teóricos como Theodor Adorno e Walter Benjamin discutem a problemática crise da representação literária diante do cenário de ruína, apontando para o esfacelamento do regimento da unidade da obra e a destituição do modo de narrar totalizante do romance realista europeu do século XIX.

A fragmentação da subjetividade atinge a unidade da obra e o exercício do narrador, na medida em que a noção de realidade a ser representada vê-se abalada pelas catástrofes históricas. Por certo, a obra de arte não é somente um produto da observação e reprodução objetiva da realidade, até porque essa é constituída por instabilidades e contradições agravadas pelas guerras, genocídios, massacres etc (CÔRTES, 2014).

Apesar da crítica literária canônica e da historiografia ocidental gravarem o evento do holocausto como marco referencial nos estudos entre literatura, testemunho e trauma, podemos deslocar o ponto de vista para perspectivas não contempladas na elaboração das narrativas históricas monológicas oficiais. A esse respeito, o filósofo e escritor anglo-ganês Kwane Appiah (1997, p. 24, grifos do autor) provoca:

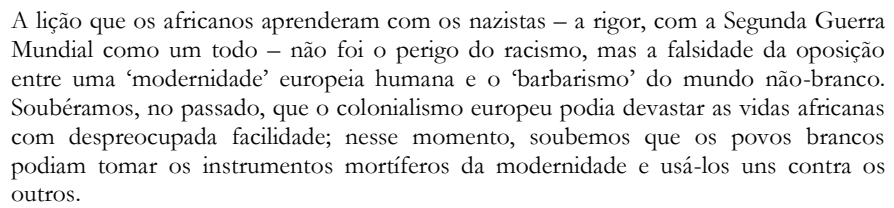

A lição que os africanos aprenderam com os nazistas - a rigor, com a Segunda Guerra Mundial como um todo - não foi o perigo do racismo, mas a falsidade da oposição entre uma 'modernidade' europeia humana e o 'barbarismo' do mundo não-branco. Soubéramos, no passado, que o colonialismo europeu podia devastar as vidas africanas com despreocupada facilidade; nesse momento, soubemos que os povos brancos podiam tomar os instrumentos mortíferos da modernidade e usá-los uns contra os outros. 
Por certo, muito da história sangrenta dos empreendimentos coloniais na África e na América Latina ainda permanece esquecida, ocultada pelo radioso brilho do progresso, que faz desses acontecimentos a própria exaltação dos valores ocidentais em regiões incivilizadas. Entretanto, esses territórios são testemunhas da força violenta, opressiva e destrutiva dos supostos agentes da civilização, os quais deixaram essas terras marcadas pela escravidão e pelo genocídio massivo de suas populações originárias. Assim, a geografia local e os povos nativos dão testemunho de como a barbárie é escondida sob os tapetes da tradição historiográfica ocidental (MATA, 2014).

A perspectiva das narrativas do trauma aliada ao campo das Literaturas Africanas em Língua Portuguesa - mais especificamente da moçambicana, nosso objeto de estudo -, institui-se enquanto espaço no qual as histórias e memórias desse passado traumático, (re)lidas com a devidas dimensões críticas e reflexivas, oportunizam a construção de discursos que denunciam a opressão, a violência sistemático-institucionalizada e as estratégias de subalternização dos sujeitos. Ademais, "a arte literária em particular [...] oferece o espaço para enfrentar e curar o trauma herdado e inscrever na história aqueles que foram silenciados, violados, esquecidos e/ou apagados por acontecimentos históricos traumáticos" (WALTER, 2011, p.08).

Portanto, as representações literárias sobre o trauma são fundamentais para pensarmos nas expressões violentas e autoritárias de sociedades estruturadas a partir de sistemas de opressão e dominação, como foi o caso do empreendimento colonial em relação às suas colônias. Em tal posição, o escritor urde as linhas das memórias individuais que se entrelaçam com as vozes de uma coletividade, para enfrentar os fantasmas doridos do passado e (re)inscrever nas páginas da história os nomes, existências e identidades que sofreram tentativas violentas de apagamento pelos poderes hegemônicos.

\section{2 "A orgia dos loucos": corpos despedaçados à procura de humanidade}

A produção literária do escritor moçambicano Ungulani Ba Ka Khosa, natural da província de Sofala, é fortemente marcada pelo seu trabalho enquanto historiador. $\mathrm{O}$ autor assume uma posição crítica em relação ao passado mal resolvido de Moçambique e propõe dicções que confrontam as memórias de guerra, dor, perda e sofrimento integrantes da construção da nação moçambicana desde o estabelecimento do domínio colonial português, passando pelo tenso processo de independência e desembocando na devastadora guerra civil.

Nesse trabalho com a memória, o ele enfatiza a necessidade de:

olhar [o passado] sem construir uma história muito cor-de-rosa. [...] Não é só recuperar esses espaços de memória, mas também carregar uma mensagem em que as pessoas no presente se confrontam com esse passado. [...] Não é só recuperar a história mas também problematizar e levar as pessoas a interrogarem-se (KHOSA, 2015, p. 15).

Na coletânea de contos Orgia dos loucos, o autor verte para a sua produção literária todo o sangue e ruína de um Moçambique corroído e devassado pelas consequências da guerra civil (1977-1992), conflito armado que durou 16 anos e vitimou mais de 1.000.000 de pessoas. Entre destroços, cadáveres, excrementos, infortúnios naturais, o tom da obra anuncia um estertor apocalíptico, apoiado pela escrita agonizante e fragmentada, na qual o insólito potencializa a linguagem hiperbólica da catástrofe. Ao lado do inacreditável do horror, produzido pela crueza da carnificina e das maquiarias mortíferas da guerra, os eventos insólitos compõem uma sinfonia hiperbólica para nos aproximar dos tons da barbárie: os lagos de vísceras, mares de sangue, corpos decompostos, inundações colossais, ruas calçadas em órgãos retalhados; são possibilidades de manifestação da linguagem do trauma, em sua feição enigmática e retorcida. 
O horizonte apocalíptico do quinto conto, homônimo ao título da obra, remete ao contexto histórico das comunidades rurais e dos pequenos povoados moçambicanos no período da guerra civil. Em 1979, há uma verdadeira política de guerrilha no interior do país, ocasião na qual se intensificam os massacres nas aldeias e vilarejos. Além disso, a implantação de minas terrestres acentua o número de mortos e mutilados durante o conflito. Até meados de 1998, Moçambique era um dos quatro países com mais minas terrestres ativas no mundo (DARTH, 2018).

Em "A orgia dos loucos", o cenário de caos surge como sinfonia e desperta, gradativamente ao coro de timbres ressonantes, as memórias enterradas do protagonista:

\begin{abstract}
Os sentidos, tal como a serpente após a muda, foram despertando do letargo a que a consciência da morte prenunciada no princípio das dores os remetera. Era noite, soube depois, mas naquele momento, como que surdindo das profundezas abissais dos espíritos, os sons foram entrando no corpo. Era o chikulo, nome que o contrabaixo das marimbas leva nessas terras, ligando as peças soltas do corpo esfacelado pela dor; era $o$ chilanzane, nomeação do soprano, abrindo as artérias do rio de sangue que os construtores da agonia estancaram com certeza apocalíptica do fim do século; era o debiinda, nome que leva o baixo, reativando o motor da rega enferrujado pelos tempos de suplício sem memória (KHOSA, 2016, p. 61).
\end{abstract}

Vislumbramos a proposição vacilante de uma "ópera" tenebrosa, que gradativamente é executada com os sons da morte e do desespero. É esse som dissonante que vibra no cenário, marcando agonicamente o despertar de um homem jogado no centro da absoluta destruição. Cada naipe vocal adiciona ao andamento do ato sua própria inscrição particular: o chikulo (contrabaixo) reverbera sobre os estilhaços corpóreos que tentam recuperar alguma unidade, a chilanzane (soprano) soa com agudez ao fazer correr o sangue represado das mutilações, lacerações, ferimentos e pústulas do corpo já anêmico de uma nação vitimada por conflitos armados desde os tempos coloniais; e o debiinda (baixo), na espessura enlutada da canção, reativa as engrenagens enferrujadas da memória, esse mecanismo já afetado com a maquinaria traumática.

Ao deambular entre escombros, iniciando sua incursão nos territórios da destruição, a existência daquele ser vagante é retirada do estado breve de esquecimento no qual se encontrava: "As imagens, em revoada, passaram-lhe pela mente. A memória acoitara-se na gruta da sua existência. - Chamo-me António Maposse. E chorou" (KHOSA, 2016, p. 62). Nesse instante, a lembrança de quem era desperta no protagonista do conto a urgência de recuperar algo além da própria identidade, lançando-o mais profundamente naquele ambiente hostil. Imediatamente, António vasculha o espaço mutilado pela guerra à procura da mulher e do filho:

$$
\begin{aligned}
& \text { Os olhos procuram. [...] Os pés tateiam o chão de sangue, tropeçam em barrotes, } \\
& \text { espezinham cérebros em farelo, dedos triturados, olhos sem dono, línguas sem céu nem } \\
& \text { terra, orelhas como búzios nas praias dos fantasmas, Maria! ... Maria... O braço. Os dedos } \\
& \text { afagam os cabelos livres do lenço. As mãos tremem. Não falas? ... Maria.... Amanhã vamos à } \\
& \text { cantina do Shakir, Maposse, vamos trocar o milho e a castanha... Maria, fala, Maria... } \\
& \text { Levamos o João, o João... sim, onde está o João, Maria? (KHOSA, 2016, pp. 61-62). }
\end{aligned}
$$

O encontro de Maposse com o cadáver da esposa é atravessado por uma linguagem fragmentária, não somente o espaço, os objetos ou as memórias são metonimicamente retalhados, mas também a própria construção narrativa se vê estilhaçada. Por conseguinte, as lembranças de Maria surgem no mesmo plano dos destroços da guerra, tão recortadas quanto as partes dos corpos espalhados pelo cenário. Podemos perceber que "nas narrativas de violência, o trauma corta, silencia a palavra restando ao narrador seus fragmentos ou flashs que remetem o leitor ou ouvinte à situação/realidade negada" (CÔRTES, 2014, p. 87, grifos nossos).

Narrar o trauma resulta também no confronto com os termos da perda e da ausência. Quanto mais o protagonista avança entre os detritos da morte à procura da família, mais forte será 
o reconhecimento do vazio instalado pela destruição. Confrontado com a morte de Maria, Maposse sente o agonizante silêncio da devastação:

\begin{abstract}
És minha... Tocaram-te... A capulana cobre o corpo. As pálpebras tapam os olhos. O rosto toma a forma dos mortos fartos do suplício terreno. O meu filho? Estará vivo? Olha de novo em redor. O mesmo silêncio. O mesmo som. A mesma voz. A mesma ausência. João! Silêncio. Os passos ressoam. A vila está de luto. A noite cresce. Os passos ressoam. A vila está de luto. A noite cresce. Os passos troam. Os olhos procuram (KHOSA, 2016, p. 63).
\end{abstract}

Estar diante do cadáver violado da mulher e da incerteza quanto ao paradeiro do filho aciona no protagonista um processo precário de experimentação da perda. Nesse sentido, o vazio e o silêncio preenchem a cena, produzindo um desconcerto inominável. A mudez do luto expande-se para além das pessoas, pois a vila personificada o sente e confunde-se com os sentidos de Antonio. Em manifestação densa, a ausência cai na profundidade dos corpos, devassando com a mesma intensidade indivíduos, coisas e locais.

Importa discutirmos a distinção entre perda e ausência em relação à historicidade do trauma, haja vista que no plano das memórias são entrelaçadas as experiências individuais e coletivas. Segundo Elisa Maria Taborda Silva:

\begin{abstract}
A perda é um trauma situado no nível histórico, uma vez que podemos localizá-la temporalmente, como no caso da morte de um ente querido. Em contrapartida, a ausência é vivida no nível do trans-histórico ou estrutural. Aqui, o trauma pulveriza-se na existência do indivíduo, que sente falta de algo que não reconhece (2015, p. 26, grifos nossos).
\end{abstract}

Por meio do itinerário de Maposse, observamos que a morte dos entes queridos é impactada por imagens brutais da guerra. Nessa perspectiva, o processamento da perda acontece no mesmo momento em que a consciência da catástrofe se instala: não há espaço para a vivência do luto individual, assim o sentido de ausência catalisa o trauma coletivo moçambicano da guerra civil. Na narrativa, o próprio país é personificado enquanto corpo retalhado, cujos órgãos estão expostos à metonímia da carnificina:

\begin{abstract}
A rua é um talho de carne humana. Braços sem dono, pernas suspensas em argolas inexistentes, corações em plásticos de areia, fígados amontoados como alforrecas entre os despojos de um naufrágio, pénis suspensos em hastes que proclamam o fim da criação, mãos emergindo do pântano de sangue, rostos imóveis, distantes, angustiados, aterrorizados, rostos sem vida. O homem afasta-se. Corre. Foge Grita. Tropeça. Cai. Rebola. Desmaia. João! ... (KHOSA, 2016, p. 64).
\end{abstract}

Nessa orgia de corpos despedaçados, Ungulani Ba Ka Khosa joga o leitor na absoluta destruição, por meio de uma narrativa estrategicamente construída a partir da cadaverização, da construção do horror como abjeto e da fragmentação do mundo em ruínas. Não obstante, mesmo diante do cenário macabro no qual António Maposse incursiona à procura da família, ainda é possível enxergar nesse gesto uma tentativa de resistência à devastação da guerra, pois "é no território fúnebre de confronto com a destruição que se manifesta o esforço da vida" (GINZBURG, 2011, p. 55). Ele tenta resistir à violenta exposição da perda do outro e de si, dentro de um ambiente hostil e desumanizador.

Aproximando-se da condição de um fantasma, António chega ao ponto máximo de sua trajetória, constatando o seguinte fato: "Estou morto. [...] Estou entre os espíritos" (KHOSA, 2016, p. 67). De tanto caminhar entre corpos e escombros, o protagonista duvida da própria existência e até mesmo da possibilidade de sentir-se vivo rodeado de tantos sinais de morte. Nem o encontro com o filho será suficiente para restituir-lhe a sensação de vida e humanidade, entregara-se a uma letargia cadavérica: 


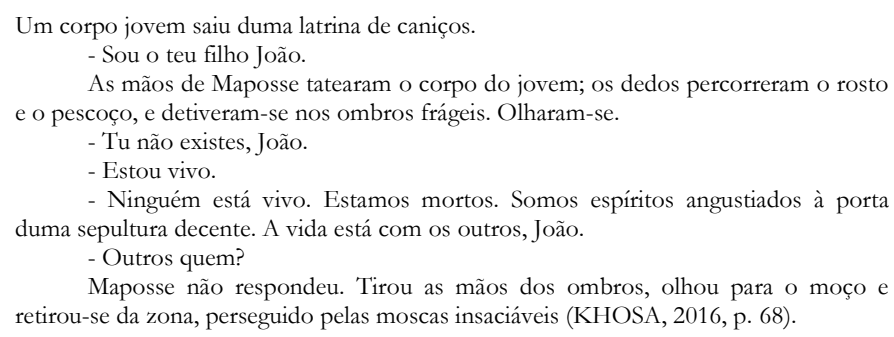

O fim da trajetória do protagonista corresponde à difícil sustentação da racionalidade do sujeito frente o evento traumático. Nesses termos, a capacidade de subjetivação do indivíduo em contextos violentos e opressivos resulta na fragmentação da percepção de si e da realidade em volta. No caso de Maposse, presenciamos seu agônico processo de desumanização, a elisão do sujeito perdido nos horrores da guerra. Ao discutir a relação entre a crítica literária e a guerra, o pesquisador Jaime Ginzburg (2012, p. 02) elucida:

\begin{abstract}
$\mathrm{Na}$ perspectiva traumática [...] o sujeito não dá conta de suas demandas, em conflito com sua própria memória, sendo incapaz de atribuir sentido completo à sua existência. Entre a totalidade e a fragmentação, cabe a pergunta: o que pode ou deve fazer um ser humano em uma guerra?
\end{abstract}

Portanto, o movimento de António Maposse em "A orgia dos loucos" guia-se pela necessidade de sentir vida em um espaço horrorizado pela carnificina da guerra. A exposição ao horror absoluto leva-o ao limite da sua compreensão de humanidade, pois, dessubjetivado, é incapaz de imaginar-se além da condição fantasmagórica na qual se coloca. No final das contas, somos, por fim, conduzidos ao seguinte questionamento: como pode o humano resistir à catástrofe da guerra? Tal questionamento é fundamental em sociedades marcadas por relações sociais violentas e pela presença de estruturas desumanizadoras de opressão, no sentido de (re)avaliar os impactos desses mecanismos no tecido do presente e nas possibilidades do futuro.

\title{
3 “O exorcismo": os fantasmas da tradição assombram o projeto revolucionário
}

Os fantasmas funcionam como perfeita metáfora para a linguagem do trauma: seres evanescentes que, por força de um passado mal resolvido, assombram o presente. Sua presençaausência indica um estado de memória que se dá pelo horror e pela tentativa de esquecimento, em um turbilhão de sensações impossíveis de serem organizadas cartesianamente. Eles guardam as dores daquilo que não pode ser esquecido e daquilo que, por vezes, fingimos esquecer.

Com efeito, o problema ao negligenciar o trabalho crítico com a memória em relação à história violenta e opressiva nas sociedades colonizadas é a não identificação, no presente, das marcas e estruturas de dominação desse passado, que são perpetuadas e constantemente atualizadas. Escritores moçambicanos tencionam esses contextos históricos, a fim de evitar uma amnésia desastrosa e nada produtiva para enfrentar os sistemas de violência e subalternidade. Desse modo, é possível compreender a inquietação de Mia Couto (2014) com o processo de pacificação que marcou o fim da guerra civil moçambicana:




verdade, aqui, escolheu-se o silêncio. Isso é uma solução falsa. Ninguém esquece. Portanto, há aqui coisas não resolvidas, que nunca se tornaram um passado claramente marcado.

Em sentido próximo ao de Mia Couto, Ungulani Ba Ka Khosa também se preocupa em abrir caixas de fantasmas do passado de Moçambique. Decerto, em "O exorcismo", o autor tematiza a tensão entre os valores das comunidades tradicionais moçambicanas e o projeto revolucionário pós-independência, no qual a FRELIMO², entre 1975 a 1977, tenta implantar um regime socialista no país. No conto, o filho do administrador da província é carregado pela correnteza do rio, enquanto admirava a beleza da jovem Hanifa. Desesperado e contrariado em suas convicções ideológicas, o pai resolve pedir auxílio ao curandeiro local, por acreditar ser obra da ira dos espíritos antigos o fatídico acontecimento.

Com o propósito de aplacar a ira dos ancestrais e resgatar Pedro, o curandeiro põe em curso um ritual de exorcismo: "Reunidos à beira do rio, e em poses indescritíveis, os homens tiraram as balalaicas da disciplina, os fatos do poder, as medalhas da luta e do trabalho, e envergaram as tangas da ancestralidade" (KHOSA, 2016, p. 83). Nota-se, na construção do cenário ritualístico, a deposição dos signos do poder revolucionário ("balalaicas da disciplina", "fatos do poder", "medalhas da luta"), como atitude necessária para a evocação dos espíritos da ancestralidade.

O discurso do trecho acima encontra respaldo na crítica empreendida pelo próprio autor no texto Memórias perdidas, identidades sem cidadania, no qual Khosa (2015, p. 129, grifos nossos) questiona se o projeto de independência abrigou a pluralidade que a nação trazia em sua constituição:

\begin{abstract}
Com a independência esperava-se, enfim, que várias tribos ganhassem cidadania e contribuíssem, na sua diversidade, para a construção do tecido identitário moçambicano. Mas tal não ocorreu. O governo da época, sob a batuta dos heróis da gesta nacionalista, transladou o princípio reinante nas zonas libertadas de matar a tribo para construir a nação. $\mathrm{O}$ III Congresso da Frelimo, acontecido dois anos depois da independência, em 1977, veio legitimar a uniformização cultural e ideológica como condição única para a Unidade Nacional.
\end{abstract}

Khosa não dissocia seu papel de historiador do escritor de ficção, há um compromisso ético, estético e político assumido em ambos os espaços de atuação. Nesse sentido, a perspectiva traumática, pela qual lemos o corpus em análise, "poderá dar conta não apenas da encenação ou elaboração de fatos violentos do passado de um indivíduo, mas também do passado de toda uma sociedade ou etnia" (SILVA, 2015, p. 13).

A presença de eventos insólitos, no conto, a exemplo da inundação que começa a partir das lágrimas de Hanifa, contribui para compor os sentidos da ilogicidade da linguagem do trauma, que já não responde ao estatuto da totalidade do sentido, nem da organização cronológica linear dos eventos: "Tudo o que era anormal entrava na lógica dos dias e das noites da morte e do desespero" (KHOSA, 2016, p. 85). Além disso, a impossibilidade da representação total das experiências traumáticas nas narrativas das literaturas africanas de língua portuguesa, também possibilita $\mathrm{O}$ questionamento das versões monológicas e hegemônicas da história oficial.

De acordo com Silva (2015, p. 33):

2 A palavra "Frelimo" - que já não é considerada uma abreviatura - tem origem no acrónimo FRELIMO (Frente de
Libertação de Moçambique). Trata-se de uma ampla frente constituída na Tanzânia em 1962, com o objectivo de
obter a Independência. A Frente manteve uma guerra de dez anos contra o poder colonial, de 1964 a 1974, e a
independência foi finalmente alcançada em 1975. Em 1977, no seu Terceiro Congresso, o movimento passou a ser
um partido de vanguarda marxista-leninista, mas, mais tarde, abandonou esta orientação ideológica sob pressão
política e económica. O Partido Frelimo é dominante em Moçambique e venceu todas as eleições gerais
multipartidárias desde 1994 (DARTH, 2018, p.06).

Revista do GELNE, Natal/RN, Vol. 22 - Número 1: p. 231-242. 2020 


\begin{abstract}
[as] narrativas desenvolvidas em consonância com a [...] estética do trauma tratam, enfim, do problema da expressão daquilo que escapa à representação literária tradicional, ao ponto de vista fechado em si mesmo. São estratégias do pensamento e da representação em busca do que se oculta, do que enfrenta dificuldades para ser colocado em palavras. É assim com os traumas em geral, inacessíveis à narrativa monológica; é assim com o componente cultural silenciado do subalterno, sem acesso à narrativa monológica da História.
\end{abstract}

Às margens do rio, no momento do desaparecimento de Pedro, a jovem Hanifa provoca uma inundação com seu pranto: “A lágrimas, misturando-se às águas [...], subiram a pequena ladeira e correram loucas [...]. Os homens, preocupados com as carências mundanas, não ligaram às águas que formaram um fio único que correu [...] em direção à administração" (KHOSA, 2016, p.85). Nesse ponto da narrativa, o itinerário aquoso que conduz o leitor até o centro administrativo da província sublinha a simbologia purificadora da água:

\begin{abstract}
As águas, alheias à comunicação humana, entraram pelos gabinetes da burocracia, espantaram os serviços estancados pela canícula tropical, e acercaram-se do gabinete do chefe. $\mathrm{O}$ administrador, com a balalaica totalmente desabotoada e os pés assentes sobre os sapatos com a dimensão de sapos de épocas perdidas, despachava processos dos candongueiros de ratos selvagens, dos adúlteros impotentes e dos poços sem água, com o polegar da mão direita, o mesmo que servia, com o apoio do indicador, para limpar ranho que teimava sair das narinas coloridas de azul, quando se apercebeu de que algo estranho passava. As águas, como larvas no cio, tornando indecifrável os processos de prostitutas em regime de reeducação e dos candongueiros de ratos selvagens (KHOSA, 2016, p.85).
\end{abstract}

É possível observar dois atos de limpeza: o primeiro relaciona-se com a compreensão da formação do novo homem e da limpeza da nação que a FRELIMO sustentava na implantação do modelo socialista de governo em Moçambique; o segundo é a própria invasão das águas, que aponta e denuncia o que historicamente ficou entorpecido na aplicação desse ideal.

São contrapostas duas imagens no excerto citado: a água em fúria e movimento e a paralisia do poder burocrático e modorrento, como se a revolução das águas denunciasse o que o projeto revolucionário deixou de fazer e, de modo mais crítico, acabou tornando-se, em muitas situações, a expressão de um governo repressivo, corrupto e autoritário. Além disso, é possível notar a menção aos campos de reeducação, lugares destinados aos considerados inimigos internos do governo.

Sintomaticamente, de acordo com o antropólogo Omar Ribeiro Thomaz (2008, p. 180, grifos do autor):

Para os campos de reeducação iriam todos aqueles que, de uma forma ou de outra, traziam consigo ou em si elementos da velha ordem que se desejava eliminar - régulos (autoridades tradicionais), feiticeiros, 'comprometidos' (indivíduos sobre quem pesava a suspeita de algum tipo de compromisso com a antiga ordem colonial), prostitutas; para os campos de trabalho todos aqueles que deveriam passar por uma ressocialização marcada pelo trabalho em grandes campos de cultivo (machambas): sabotadores, inimigos, vadios.

De fato, em "O exorcismo", o administrador assume o discurso de "matar a tribo para construir a nação". Tanto que, na ocasião do desaparecimento do primogênito, esgotados todos os recursos racionais para encontrá-lo, um de seus homens lhe sugere procurar Simamba, o curandeiro local. Contudo, ao eventual contato com o curandeiro, o chefe da província adverte os seus homens para que a comunidade seja informada de que aquele ritual faz parte de "uma experiência revolucionária":

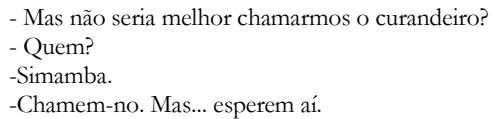




\begin{abstract}
Soergueu-se. Limpou as calças. Aproximou-se dos homens que o olhavam com a inocência das lebres em zoos carentes e disse:

- Não quero cartas aos leitores nem relatórios falsos às estruturas centrais. $\mathrm{O}$ que vamos fazer aqui não deve sair deste distrito. Não quero ouvir histórias. Não quero intrigas, boateiros, reacionários, contrarrevolucionários, inimigos da pátria, ouviram? Aqui não entra superstição, curandeirismos! O que vamos fazer. Camaradas, enquadra-se nas experiências revolucionárias. Entenderam? (KHOSA, 2016, p. 88, grifos nossos).
\end{abstract}

Negar os símbolos e tradições das comunidades locais resulta num processo de assepsia, como se nova pátria solicitasse ser assentada em alicerces outros, estruturas que indicassem progresso e civilização. Assim sendo, a recusa em admitir necessitar dos saberes da ancestralidade faz com que o chefe da província transfigure o ritual de exorcismo em uma "experiência revolucionária". Nenhum misticismo deve vigorar nesse edifício cimentado da racionalidade, no qual os fenômenos devem ser perscrutados à exaustão, a fim de evitar todo engano das supertições e curandeirismos. Nesse sentido, os valores das comunidades locais são concebidos como entraves ao êxito da experiência da revolução.

Durante o processo ritualístico, o chefe da província atesta sua impotência diante dos desígnios e mistérios dos poderes ancestrais: "o administrador, num lampejo de clarividência, tomou consciência, pela primeira vez, da sua figura ridícula, da sua subserviência a poderes ocultos e da sua incapacidade em rebelar-se às forças ocultas" (KHOSA, 2016, p.90). Mais adiante, como parte do ritual, o homem de poder entrega ao curandeiro os documentos que "identificavam o filho como cidadão da pátria" (KHOSA, 2016, p.91), os quais são queimados, em um gesto que termina por submeter o arrogante governo revolucionário aos ecos e vozes das comunidades tradicionais que tanto rechaçava.

Com o fim do exorcismo, o curso dos acontecimentos parece entrar em estado de ordem: "como que vindo de espaços interestelares, o corpo de Pedro flutuava na posição que os mortos levam nas tumbas cristãs. O curandeiro, admirado e intrigado, pediu apressadamente uma canoa" (KHOSA, 2016, p.91). Contudo, o breve momento de paz instaurado é perturbado por imagens de horror:

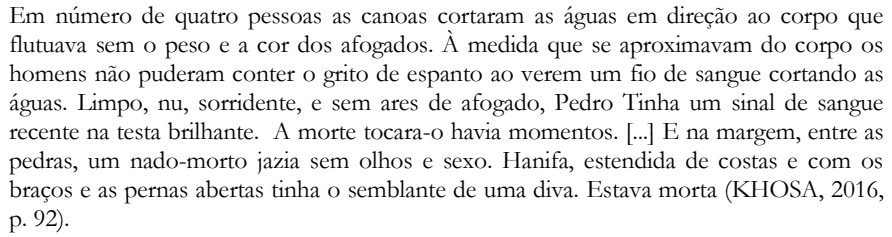

Em número de quatro pessoas as canoas cortaram as águas em direção ao corpo que flutuava sem o peso e a cor dos afogados. À medida que se aproximavam do corpo os homens não puderam conter o grito de espanto ao verem um fio de sangue cortando as águas. Limpo, nu, sorridente, e sem ares de afogado, Pedro Tinha um sinal de sangue recente na testa brilhante. A morte tocara-o havia momentos. [...] E na margem, entre as pedras, um nado-morto jazia sem olhos e sexo. Hanifa, estendida de costas e com os braços e as pernas abertas tinha o semblante de uma diva. Estava morta (KHOSA, 2016, p. 92).

As imagens do cadáver flutuante de Pedro, da morte de Hanifa e do natimorto sem olhos e sexo, representam um projeto revolucionário falido de pátria que tentou limpar Moçambique daquilo que, substancialmente, constitui o seu corpo enquanto nação: a pluralidade étnica e a multiplicidade das tradições locais. Apoiados em uma concepção de uniformidade da nação para a gestação do novo homem, os revolucionários negaram o direito à cidadania às inúmeras etnias e povos autóctones, que sofrem desde os processos de Independência com o apagamento de suas identidades.

Nesse sentido, aponta Khosa (2015, p. 130)

Os primeiros anos de independência foram fulcrais na definição da pauta da nossa sinfonia cultural. Esmagamos as notas da diversidade, silenciamos as vozes que vinham das furnas do tempo e, movidos por pretensões ideológicas de difícil sustentação, tentamos erigir um corpo, permitam-me o empréstimo, sem ADN, incaracterístico, insosso, descolorido, de voz monótona, desenraizada, totalmente à deriva. Perdemos, na 
euforia da libertação, a oportunidade de libertar a memória e de traçar, com inteira liberdade, o nosso destino cultural.

Efetivamente, torna-se imprescindível a revisitação dos fantasmas que assombram as vozes monológicas da história. A partir da exposição da ruína, do esfacelamento da realidade como unidade de sentido, da fragmentação da organização narrativa, do fluxo intempestivo de lembranças, da evasão de eventos insólitos no curso dos acontecimentos, a perspectiva do trauma nas literaturas africanas em Língua portuguesa tenciona e problematiza os contextos históricos de opressão e subalternidade.

\section{CONSIDERAÇÕS FINAIS}

Os contos, em seus desdobramentos, apontam as representações literárias como forma de travessia dos traumas individuais e coletivos. Se as partes mutiladas representam identidades que se perderam na violência física da morte, em contraponto, na literatura, tais fragmentados evocam memórias de uma coletividade. Assim, cada excerto se une a outro e, coletivamente, se recriam memórias, vivências, subjetividades que nem mesmo a morte apaga. Tal como as memórias dos mortos se marcam no presente, os traumas dos vivos resistem e se recriam, a narrar, a contrapelo, os horrores das violências e a resistir, em uma orgia que convida aos sobreviventes e às gerações vindouras a dizer: não esqueçam, resistam. De corpos em corpos, das orgias dos que vivem, outra história, outro Moçambique é possível.

\section{REFERÊNCIAS}

APIAH, Kwame Anthony. Na casa de meu pai: a África na filosofia da Cultura. Rio de Janeiro: Contraponto, 1997.

CÔRTES, Cristiane Ribeiro. Violência, silenciamento, literatura: a experiência do Fora e a denúncia da realidade. Em Tese, [S.1.], v. 20, n. 2, p. 79-93, ago. 2014. Disponível em: http://periodicos.letras.ufmg.br/index.php/emtese/article/view/6103/6003. Acesso em: 08 abr. 2020 .

COUTO, Mia. Para Mia Couto, é preciso resolver o passado de Moçambique para curar o presente. [Entrevista cedida a] Estevan Muniz. Rede Brasil atual, São Paulo, 2014. Disponível em: https://www.redebrasilatual.com.br/entretenimento/2014/04/para-mia-couto-e-precisoresolver-o-passado-de-mocambique-para-curar-o-presente-9008.html. Acesso em: 23 jun. 2018

BENJAMIN, Walter. O narrador. In: Paulo, Abril Cultural, 1983. p. 53-85.

Textos escolhidos. Coleção Os Pensadores. São

DARTH, Colin. Uma história de sucesso que ocorreu mal? O conflito moçambicano e o processo de paz numa perspectiva histórica. Maputo: Friedrich-Ebert-Stuftung, 2018.

GINZBURG, Jaime. Ditadura e estética do trauma: exílio e fantasmagoria. In: O rosto escuro de Narciso: ensaios sobre literatura e melancolia [S.l: s.n.], 2004.

GINZBURG, Jaime. Estética da morte. Gragoatá, [S.1.], v. 16, n. 31, dez. 2011. Disponível em: http://www.gragoata.uff.br/index.php/gragoata/article/view/137. Acesso em: 08 jul. 2018. 
GINZBURG, Jaime. A guerra como problema para os estudos literários. In: ORGANON Revista do Instituto de Letras da UFRGS, [S.1], v. 27, n. 52. p. 01-08, 2012. Disponível em: http://seer.ufrgs.br/index.php/organon/article/view/33473/21346. Acesso em 01 de jul. de 2018.

HALBWACHS, Maurice. A memória coletiva. São Paulo, Editora Vértice, 1990.

KHOSA, Ungulani Ba ka. A orgia dos loucos. In: Orgia dos loucos. São Paulo: Kapulana, 2016. p. $61-70$.

KHOSA, Ungulani Ba Ka. Entrevista a Ungulani Ba Ka Khosa. [Entrevista concedida a] Doris Wieser. Mulemba, Rio de Janeiro, v. 12, n. 1, p. 4-20, jan./jun. 2015.

MATTA, Inocência. Estudos pós-coloniais: desconstruindo genealogias eurocêntricas. Civitas Revista de Ciências Sociais, [S.1.], v. 14, n. 1, p. 27-42, abr. 2014. Disponível em: http://revistaseletronicas.pucrs.br/ojs/index.php/civitas/article/view/16185/10957. Acesso em: 08 abr. 2020.

MOREIRA, Terezinha Taborda. História, violência e trauma na escrita literária angolana e moçambicana. Cadernos CESPUC de pesquisa. Belo Horizonte. n. 27, p. 13-35, 2015. Disponível em: http://periodicos.pucminas.br/index.php/cadernoscespuc/article/view/11649. Acesso em: 12 de jun. de 2018.

SELIGMANN-SILVA, Márcio. Literatura e trauma. Pro-posições. Campinas (SP), vol. 13, n. 3, p. 135-153, 2002. Disponível em: Disponível em:

https://periodicos.sbu.unicamp.br/ojs/index.php/proposic/article/view/8643943/11399. Acesso em: 14 jul. 2018.

SELIGMANN-SILVA, Márcio. Narrar o trauma. A questão dos testemunhos de catástrofes históricas. Revista de Psicologia Clínica. Rio de Janeiro, vol. 20, n. 1, p. 65-82, 2008. Disponivel em: http://www.scielo.br/scielo.php?pid=S0103-

56652008000100005\&script=sci_arttext. Acesso em: 28 de jun. 2018.

SILVA, Elisa Maria Taborda da. Estética do trauma e poética da relação: uma aproximação possível. Cadernos CESPUC de pesquisa. Belo Horizonte. n. 27, p. 13-35, 2015. Disponível em: http://periodicos.pucminas.br/index.php/cadernoscespuc/article/view/P23583231.2015n27p13. Acesso em: 20 de jun. de 2018.

THOMAZ, Omar Ribeiro. "Escravos sem donos": a experiência social dos campos de trabalho em Moçambique no período socialista. Revista de Antropologia, v. 51, n. 1, p. 177-214, 1 jan. 2008. Disponível em: http://www.revistas.usp.br/ra/article/view/27305. Acesso em: 20 jul. 2018.

WALTER, Roland. Violência e trauma: mapas do corpo negro. In: Anais da Associação Brasileira de Literatura Comparada. Curitiba: ABRALIC, 2011.

Submetido em 16/12/2019

Aceito em 17/04/2020

Publicado em 26/05/2020

Revista do GELNE, Natal/RN, Vol. 22 - Número 1: p. 231-242. 2020 